E3S Web of Conferences 1, 41028 (2013)

DOI: $10.1051 / \mathrm{e} 3$ sconf/20130141028

(C) Owned by the authors, published by EDP Sciences, 2014

\title{
Comparison of the sample collection strategies for the investigation of pollution stage of some heavy metals in marine sediments
}

\author{
A. Baysal, T. Manasir Oz ${ }^{2}$ and S. Akman \\ Istanbul Technical University, Faculty of Science and Letters Department of Chemistry, 34469, Maslak, Istanbul, \\ ² GISAŞ Gemi İnşa San.A.Ş., Tuzla Istanbul
}

\begin{abstract}
In this work, sampling collection strategies were compared for the determination of some heavy metals $(\mathrm{Pb}, \mathrm{Cr}, \mathrm{Ni})$ and investigate their effects on the marine pollution. The sampling area is a natural bay using as a shipbuilding industries for three decades especially. To determine the permanent heavy metal pollution in this area, the sediment samples were taken different strategies; i) the bay were divided square pieces which is $200 \mathrm{~m}$ length, and the samples were taken this distance (total 71 point), ii) the samples were taken along the shore, then $200 \mathrm{~m}$ away the shore and $400 \mathrm{~m}$ away the shore (total 58 point). After the sample collection using ISO 5667-12 and EPA sampling procedure, the samples were prepared for the metal analysis. Acid treated samples were analyze by graphite furnace atomic absorption spectrometry. As a results both strategies were (are) compared for investigation of some heavy metals pollution in marine sediment. The preliminary results were found between below LOD and $401.0 \mathrm{mg} / \mathrm{kg}$ for lead, and between 0.10 and $1005.0 \mathrm{mg} / \mathrm{kg}$ for chromium. Finally, the permanent heavy metal pollution is investigated in this bay.
\end{abstract}

Keywords: Heavy metals, marine sediment, sampling strategy

\section{Introduction}

Pollution of the natural environment by heavy metal is a serious problem for whole world as these metals are indestructible and have toxic effects on living organism when they exceed certain contraction and exposure.

Sediments are mixture of several components including different metal. Sediments are one of the ultimate sinks for heavy metal discharged into environment.

The aim of this study is identify any heavy metal exposure in the bay using sediment samples or have any permanent exposure or not in this area, and compare the sample collection strategies to determine heavy metal exposure.

\section{Materials and Methods}

A Varian $280 \mathrm{Z}$ graphite furnace atomic absorption spectrophotometer was used for the determination of metal analysis. Coded hollow cathode lamps were used each of the analyte as the spectral radiation sources. High-purity water (resistivity $18.2 \mathrm{M} \Omega . \mathrm{cm}$ ) obtained by a TKA reverse osmosis and a TKA deionizer system (TKA Wasseraufbereitungsysteme $\mathrm{GmbH}$, Niederelbert Germany) was used for all dilutions. All chemicals were of analytical grade (Merck, Germany, www.merck-chemicals.com; Fluka, Switzerland, www.sigmaaldrich.com). All samples were collected using
EPA standart or equal standardization guidance on sampling of bottom sediments, handling of samples and storage procedure.

\section{Sample collection and preparation for analytical procedure}

The sediment samples were taken different strategies; i) the bay were divided square pices which is $200 \mathrm{~m}$ length, and the samples were taken this distance (total 65 point), ii) the samples were taken along the shore, then $200 \mathrm{~m}$ away the shore and $400 \mathrm{~m}$ away the shore (total 58 point). After the collection, the samples were storaged using EPA guidelines in polyproplyne storage container. 1-2 g sample (wet weight) to a vessel adding $10 \mathrm{~mL} \mathrm{HNO3}$. The mixture of dried sediment samples and acid vigorously digested under controlled conditions to solubilize all of the metals. Following digestion, the sample were filtered. The samples were analyzed by atomic absorption (AA) spectroscopy using the EPA Method 1669.

\section{Results and Discussion}

In order the investigate effective collection strategies for heavy metal exposure and determination, the samples are analyzed by GFAAS after acid treatment. The preliminary results is only made a sampling strategy. Later we will give detail information about sampling area, sample coordinates, and other information about sampling, then discuss the results and show the statistical analysis. 


\section{References}

U.S. Geological Survey Techniques of Water-Resources Investigations, Book 9 Handbooks for Water-Resources Investigations National Field Manual for the Collection of Water-Quality Data, Revised 2006.

EPA, QA/QC Guidance for Sampling and Analysis of Sediments, Water, and Tissues for Dredged Material Evaluations Chemical Evaluations, 1995.

EPA, Recommended Guidelines For Measuring Metals In Puget Sound Marine Water, Sediment And Tissue Samples, 1997. 